\title{
Ethnopharmacology and Therapeutic Value of Bridelia micrantha (Hochst.) Baill. in Tropical Africa: A Comprehensive Review
}

\begin{abstract}
Alfred Maroyi
Medicinal Plants and Economic Development (MPED) Research Centre, Department of Botany, University of Fort Hare, Private Bag X1314, Alice 5700, South Africa; amaroyi@ufh.ac.za; Tel.: +27-71-960-0326

Received: 18 August 2017; Accepted: 5 September 2017; Published: 8 September 2017

Abstract: Bridelia micrantha is traditionally used in tropical Africa to treat a wide range of human and animal diseases. The aim of this study was to summarise the research that has been done on the ethnomedicinal uses, phytochemistry and pharmacological properties of B. micrantha so as to understand its importance and potential value in primary healthcare systems. The literature search for information on ethnomedicinal uses and pharmacological activities of B. micrantha was undertaken using databases such as Web of Science, Scopus, Google Scholar, Science Direct, BioMed Central (BMC), PubMed and Springerlink. Other relevant literature sources included books, book chapters, websites, theses, conference papers and other scientific publications. This study showed that B. micrantha is used as herbal medicine in just over half (57.3\%) of the countries in tropical Africa where it is indigenous. A total of 54 ethnomedicinal uses of $B$. micrantha have been recorded with a high degree of consensus on burns, wounds, conjunctivitis, painful eyes, constipation, gastric ulcers, cough, headache, rheumatism, painful joints, dysentery, ethnoveterinary medicine, malaria, sexually transmitted infections, stomach ache, tape worms and diarrhoea. Different plant parts, aqueous and organic extracts exhibited anthelmintic, antimicrobial, anticonvulsant and sedative, antidiabetic, antidiarrhoeal, antinociceptive, antioxidant, antiplasmodial, antischistosomal, hepatoprotective, insecticidal and $\beta$-lactamase inhibitory activities.
\end{abstract}

Keywords: Africa; Bridelia micrantha; ethnopharmacology; herbal medicine; traditional uses

\section{Introduction}

Bridelia micrantha (Hochst.) Baill. is a small to medium sized tree belonging to the family Phyllanthaceae (formerly Euphorbiaceae), commonly known as mitzeerie or coastal golden leaf [1]. The genus name "Bridelia" was coined in honour of Samuel Elisée Bridel-Brideri (1761-1828), a Swiss-German muscologist [2]. The species name, "micrantha" means "small-flowered" [2], in reference to the species' very small flowers in auxillary clusters [3]. The genus Bridelia includes approximately 60-70 species found throughout tropical and subtropical regions of the world, particularly Africa and Asia [3,4]. Several Bridelia species are used in traditional medicine throughout the world as an anthelmintic, antiamebic, antianemic, antibacterial, anticonvulsant, antidiabetic, antidiarrhoeal, antiinflammatory, antimalarial, antinociceptive, antiviral, hypoglycemic and for abdominal pain, cardiovascular, gynecological and sexual diseases [4]. Thus it is not surprising that the bark, leaves and roots of B. micrantha are widely used as herbal medicines in tropical Africa [1], while the round and black berries of the species are widely eaten, particularly by children and can be used to make jams and juices [5,6]. B. micrantha has been identified as one of the few plant species that should be integrated in the domestication process in farming systems in sub-Saharan Africa to support medicinal, nutritional and income security of local communities through household use and marketing of its fresh or dried fruits [7]. At present, B. micrantha is domesticated as a fruit tree in Malawi [8] 
and as a medicinal tree in Tanzania [9]. Due to its popularity as a herbal medicine, B. micrantha is sold as such in the herbal medicine or "muthi" markets in Cameroon [10], Malawi [11], Nigeria [12] and South Africa [13]. B. micrantha is also an important timber tree species in tropical Africa, and the species is being overexploited as a source of wood for construction, poles, furniture, mortars, spoons and tool handles in Ethiopia [1,14] and Kenya [1]. The present review is aimed at documenting the ethnomedicinal uses, biological activities and the correlated chemical compounds of B. micrantha with emphasis on the validation of the ethnopharmacological uses of the species. Results of this review are expected to reveal research challenges and perspectives required to address the knowledge gaps of this important medicinal plant species in tropical Africa.

\section{Research Methodology}

B. micrantha and other historical names and synonyms of the species such as Bridelia abyssinica Pax, Bridelia abyssinica Pax var. densiflora Gehrm., Bridelia mildebraedii Gehrm., Bridelia speciosa Müell. Arg. var. trichoclada Müell. Arg., Bridelia stenocarpa Müell. Arg., Bridelia zanzibarensis Vatke \& Pax, Candelabria micrantha Hochst. as well as common names such as "Benin ironwood", "coastal golden leaf", "mitzeerie" and "Yoruba ironwood" were used as the keywords in searching the major databases including Web of Science, Scopus, Google Scholar, Science Direct, BioMed Central (BMC), PubMed and Springerlink documenting traditional uses, medicinal uses, ethnobotany, ethnomedicinal uses, ethnopharmacology, pharmacology, phytochemistry and therapeutic value of the species. Additional literature, including pre-electronic literature such as scientific articles, conference papers, books, book chapters, dissertations, these and other grey material were sourced from the University of Fort Hare library in South Africa.

\section{Occurrence, Distribution and Botanical Description}

B. micrantha has been recorded in several countries throughout tropical Africa (Figure 1). The species has also been introduced on Réunion Island as a medicinal plant and is now naturalized on the island [1]. B. micrantha is found in a variety of habitats, ranging from savanna and woodland to seasonally flooded grassland, riverine forest, swamp forest and the margins of mangrove swamps, often from sea-level in West Africa to around $2500 \mathrm{~m}$ altitude in East Africa [1]. B. micrantha is a pioneer species that tolerates a wide diversity of soils, different rainfall regimes and can withstand moderate frost.

B. micrantha is an evergreen or deciduous, monoecious small to medium-sized tree up to $27 \mathrm{~m}$ tall with a short, often twisted bole up to $100 \mathrm{~cm}$ in diameter and a rounded crown [3]. The bark of $B$. micrantha is silver-grey to black in colour, smooth or rough with lenticels and reticulately fissured and flaking [2,3]. Young branches of B. micrantha often have spines and occasionally blunt spines are found on older branches. Leaves are simple, entire, distichous, often alternate, glabrous to slightly hairy, elliptical to oblong in shape. Flowers occur in clusters in leaf axils, yellow in colour, unisexual with triangular sepals and small petals [2,3]. Male flowers have stamens and filaments that are fused into a column at the base, but free and spreading above with rudimentary ovary. Female flowers are nearly sessile with ovary and styles fused at the base. The fruit is a globose, fleshy drupe, black in colour when ripe with brownish seeds [3]. 


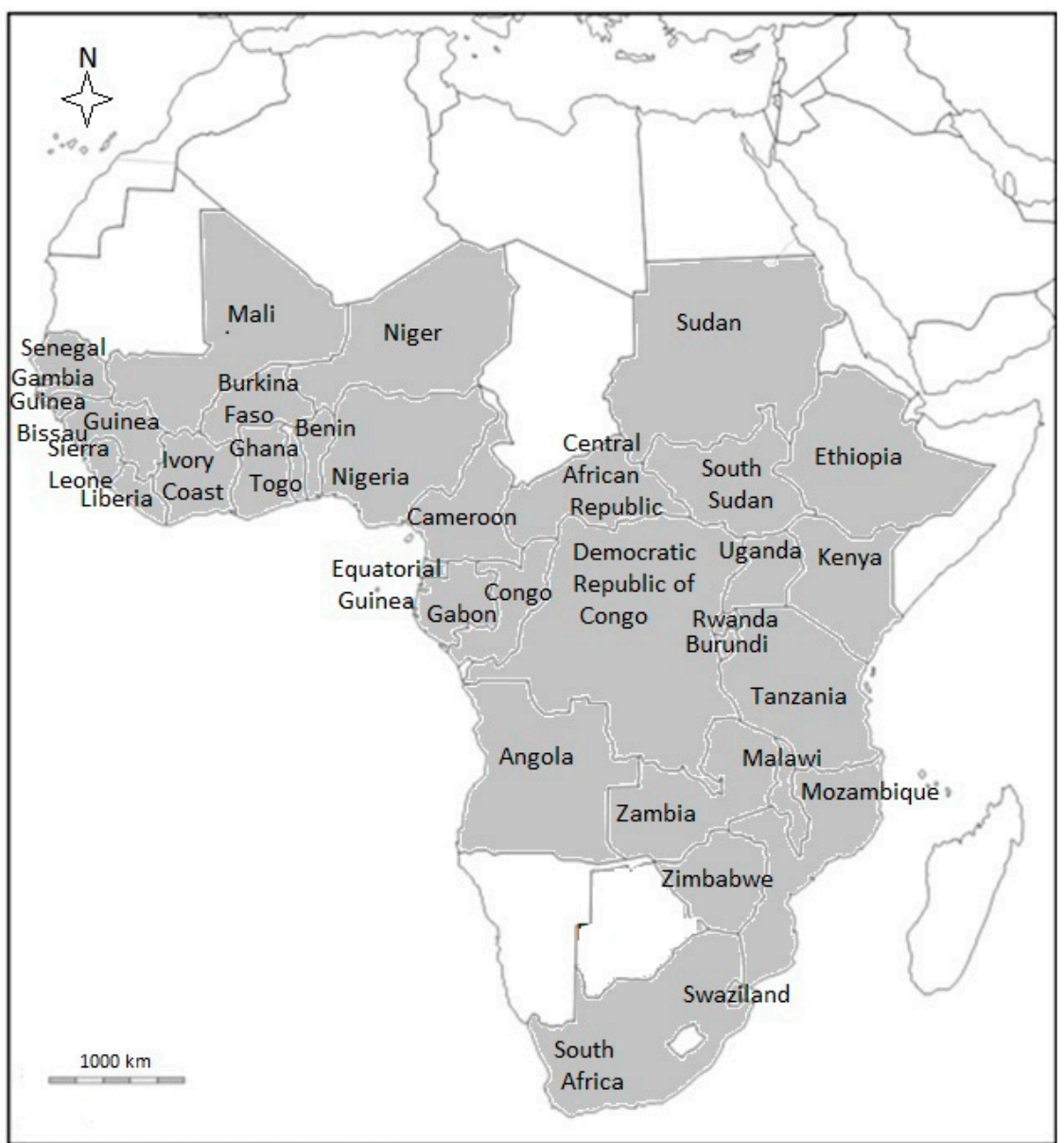

Figure 1. Distribution of B. micrantha in the mainland tropical Africa.

\section{Ethnomedicinal Uses of B. micrantha}

The bark, leaf sap, leaves and roots of B. micrantha are reported to possess diverse medicinal properties and cure various human ailments and diseases throughout its distribution range in tropical Africa. A total of 54 ethnomedicinal uses of B. micrantha have been recorded (Table 1).

There is cross-cultural agreement among ethnomedicinal uses of $B$. micrantha with a high degree of consensus on burns and wounds, conjunctivitis and painful eyes, constipation, gastric ulcers, cough, headache, rheumatism and painful joints, dysentery, ethnoveterinary medicine, malaria, sexually transmitted infections (STIs), stomach ache, tape worms and diarrhoea (Figure 2). Ethnomedicinal information has been found in Burkina Faso, Burundi, Cameroon, Democratic Republic of Congo (DRC), Ethiopia, Gambia, Ghana, Guinea, Guinea-Bissau, Ivory Coast, Kenya, Nigeria, Sierra Leone, South Africa, Tanzania, Uganda and Zimbabwe, representing $57.3 \%$ of the countries where B. micrantha is indigenous. The country with the highest ethnomedicinal uses is South Africa ( 20 based on 12 literature records), followed by Cameroon with 18 uses and six literature records, DRC with 14 uses and three literature records, Tanzania with 12 uses and five literature records, Kenya with 11 uses and six literature records, and Nigeria with nine uses and seven literature records. 
Table 1. Ethnomedicinal uses of B. micrantha in tropical Africa.

\begin{tabular}{|c|c|c|c|}
\hline Use & Plant Parts Used & Country Practiced & References \\
\hline Abdominal pain & Bark, leaf and root decoction taken orally & DRC, Uganda & {$[15,16]$} \\
\hline Abortifacient & Bark decoction taken orally & South Africa, Zimbabwe & {$[5,17-19]$} \\
\hline Amenorrea & Root decoction taken orally & Tanzania & {$[20]$} \\
\hline Amoebic dysentery & Bark decoction taken orally & Cameroon & [21] \\
\hline Anaemia & Bark, leaf or root decoction taken orally & $\mathrm{DRC}$ & {$[16,22]$} \\
\hline Anaesthetic & $\begin{array}{c}\text { Root decoction taken orally mixed with roots } \\
\text { of Vangueria infausta Burch. (Rubiaceae) and } \\
\text { Dichrostachys cinerea (L.) Wight \& Arn. } \\
\text { (Fabaceae) }\end{array}$ & South Africa & [2] \\
\hline Burns & Bark decoction applied on affected body part & South Africa & {$[2,23-25]$} \\
\hline Cancer & Bark decoction taken orally & Kenya & [26] \\
\hline Cervical, breast, skin colorectal cancer & Leaves, roots and stem bark taken orally & Kenya & [27] \\
\hline Chest complaints & $\begin{array}{c}\text { Bark decoction taken orally mixed with } \\
\text { Pittosporum viridiflorum Sims (Pittosporaceae) }\end{array}$ & Cameroon & [28] \\
\hline Conjunctivitis & Bark, leaf or root decoction applied to eyes & Cameroon, DRC & {$[16,29]$} \\
\hline Constipation & Bark, leaf or root decoction taken orally & DRC, Gambia, Ivory Coast & {$[16,30,31]$} \\
\hline Cough & Bark, leaf or root decoction taken orally & Cameroon, DRC, Zimbabwe & {$[16,18,21,22,32]$} \\
\hline Cough & $\begin{array}{l}\text { Bark decoction taken orally mixed with } \\
\text { P. viridiflorum }\end{array}$ & Cameroon & [28] \\
\hline Cough & $\begin{array}{l}\text { Bark mixed with Capsicum frutescens } \mathrm{L} \text {. } \\
\text { (Solanaceae) }\end{array}$ & Nigeria & {$[33]$} \\
\hline Dermatitis & $\begin{array}{l}\text { Bark, leaf or root decoction applied to } \\
\text { affected body part }\end{array}$ & Cameroon & [29] \\
\hline Diabetes mellitus & Bark decoction taken orally & Cameroon, Guinea, Nigeria & [34-37] \\
\hline
\end{tabular}


Table 1. Cont.

\begin{tabular}{|c|c|c|c|}
\hline Use & Plant Parts Used & Country Practiced & References \\
\hline Diarrhoea & Bark, leaf or root decoction taken orally & $\begin{array}{l}\text { Cameroon, DRC, Kenya, Nigeria, } \\
\text { South Africa, Tanzania }\end{array}$ & {$[2,9,16,22,25,32,36,38-41]$} \\
\hline Dysentery & Bark, leaf or root decoction taken orally & Burundi, Cameroon, DRC, Gambia & {$[16,36,42,43]$} \\
\hline Dysentery & $\begin{array}{l}\text { Bark taken orally mixed with Antrocaryon } \\
\text { klaineanum Pierre (Anacardiaceae) and } \\
\text { Treculia africana Decne. ex Trécul (Moraceae) }\end{array}$ & Nigeria & [33] \\
\hline Dysmenorrhea & Root decoction taken orally & Tanzania & {$[20]$} \\
\hline Emetic & Bark infusion taken orally & South Africa & {$[44]$} \\
\hline Epigastric pain & Root decoction taken orally & Tanzania & [45] \\
\hline Eye diseases & Bark decoction applied to the eyes & Cameroon & [32] \\
\hline Fever & Bark, leaf or root decoction taken orally & DRC, South Africa & {$[16,23]$} \\
\hline Gastric ulcers & Bark, leaf or root decoction taken orally & Cameroon, DRC, South Africa & {$[16,32,46]$} \\
\hline Gastro-Intestinal ailments & Bark decoction taken orally & South Africa & [25] \\
\hline Guinea worm & Leaf decoction taken orally & Ghana & [34] \\
\hline Haemorrhoids & Bark, leaf or root decoction taken orally & DRC, Guinea-Bissau & {$[16,22,47,48]$} \\
\hline Headache & $\begin{array}{l}\text { Bark, leaf or root decoction sometimes with } \\
\text { oil or butter rubbed into scalp }\end{array}$ & DRC, Nigeria, South Africa, Tanzania & {$[9,16,23,45,49,50]$} \\
\hline Hernia & Leaf or bark decoction taken orally & Tanzania & {$[51]$} \\
\hline $\mathrm{HIV} / \mathrm{AIDs}$ & Bark decoction taken orally & Kenya & {$[52]$} \\
\hline Induce labour pains & Bark decoction taken orally & Nigeria & {$[53]$} \\
\hline Infertility & Bark decoction taken orally & Cameroon & [36] \\
\hline Infertility & $\begin{array}{l}\text { Root decoction taken orally mixed with roots } \\
\text { of P. africanum Sond. and Ochna spp. } \\
\text { (Ochnaceae) }\end{array}$ & South Africa & [54] \\
\hline
\end{tabular}


Table 1. Cont.

\begin{tabular}{|c|c|c|c|}
\hline Use & Plant Parts Used & Country Practiced & References \\
\hline Insomnia & Bark decoction taken orally & Cameroon & [55] \\
\hline Malaria & Bark, leaf or root decoction taken orally & $\begin{array}{c}\text { Guinea, Ivory Coast, Kenya, South } \\
\text { Africa, Tanzania }\end{array}$ & {$[20,23,56-59]$} \\
\hline Migraine & Bark, leaves or root decoction taken orally & Nigeria & {$[49,50]$} \\
\hline Muscle pain & Bark decoction rubbed on painful muscles & Cameroon & [55] \\
\hline Numbness of feet & Bark decoction rubbed on feet & Cameroon & {$[55]$} \\
\hline Painful joints & Bark decoction rubbed on painful joints & Kenya, South Africa & {$[25,60]$} \\
\hline Pain killer & $\begin{array}{l}\text { Roots taken orally mixed with roots of } V \text {. } \\
\text { infausta and D. cinerea }\end{array}$ & South Africa & [54] \\
\hline Paralysis & Bark decoction taken orally & South Africa & [25] \\
\hline Physical weakness & Bark decoction taken orally & Cameroon & [55] \\
\hline Pre-Hepatic jaundice & Bark decoction taken orally & Uganda & {$[61]$} \\
\hline Purgative for poisoning & Leaf decoction taken orally & Ivory Coast & [31] \\
\hline Rheumatism & Bark, leaf or root decoction taken orally & Cameroon, Tanzania & {$[29,51]$} \\
\hline Sexual weakness & Bark decoction taken orally & Cameroon & [55] \\
\hline Skin eruption & $\begin{array}{l}\text { Bark or leaf decoction applied to affected } \\
\text { body part }\end{array}$ & Kenya, Tanzania & {$[51,62]$} \\
\hline Spleen enlargement & Bark or leaf decoction taken orally & Tanzania & [51] \\
\hline Sexually transmitted diseases (STDs) & Bark, leaf or root decoction taken orally & Guinea-Bissau, Kenya & {$[47,60,63]$} \\
\hline Scorpion bite & Bark decoction applied to affected body part & Ethiopia & [64] \\
\hline Sore eyes & $\begin{array}{l}\text { Bark, leaf sap or leaf decoction } \\
\text { applied on eyes }\end{array}$ & South Africa, Tanzania & {$[2,23,39,45,46]$} \\
\hline Stomach ache & Bark, leaf or root decoction taken orally & $\begin{array}{c}\text { Guinea-Bissau, Kenya, Nigeria, South } \\
\text { Africa, Tanzania }\end{array}$ & {$[38-41,47,48,51,60]$} \\
\hline
\end{tabular}


Table 1. Cont.

\begin{tabular}{|c|c|c|c|}
\hline Use & Plant Parts Used & Country Practiced & References \\
\hline Syphilis & $\begin{array}{l}\text { Bark decoction taken orally mixed with } \\
\text { Mangifera indica L. (Anacardiaceae) }\end{array}$ & Sierra Leone & {$[65]$} \\
\hline Syphilis & Bark or leaf decoction taken orally & Uganda & [61] \\
\hline Tape worms & Bark or leaf decoction taken orally & $\begin{array}{c}\text { Cameroon, Kenya, Nigeria, } \\
\text { South Africa, Tanzania, Uganda }\end{array}$ & {$[2,9,15,25,32,38,41,60]$} \\
\hline Toothache & Bark decoction applied to affected teeth & DRC, South Africa & {$[2,22,23,25]$} \\
\hline Tumor & Stem bark decoction taken orally & Kenya & [26] \\
\hline Venereal diseases & Bark or leaf decoction taken orally & Kenya, South Africa & {$[2,23,25,38]$} \\
\hline Wounds & $\begin{array}{l}\text { Bark, leaf or root decoction applied to } \\
\text { affected body part }\end{array}$ & DRC, Sierra Leone, South Africa & {$[2,16,23-25,65]$} \\
\hline Yellow fever & Root decoction taken orally & Tanzania & {$[20]$} \\
\hline Ethnoveterinary medicine & & $\begin{array}{l}\text { Burkina Faso, DRC, Ethiopia, } \\
\text { Kenya, Uganda }\end{array}$ & {$[14,60,66-68]$} \\
\hline
\end{tabular}




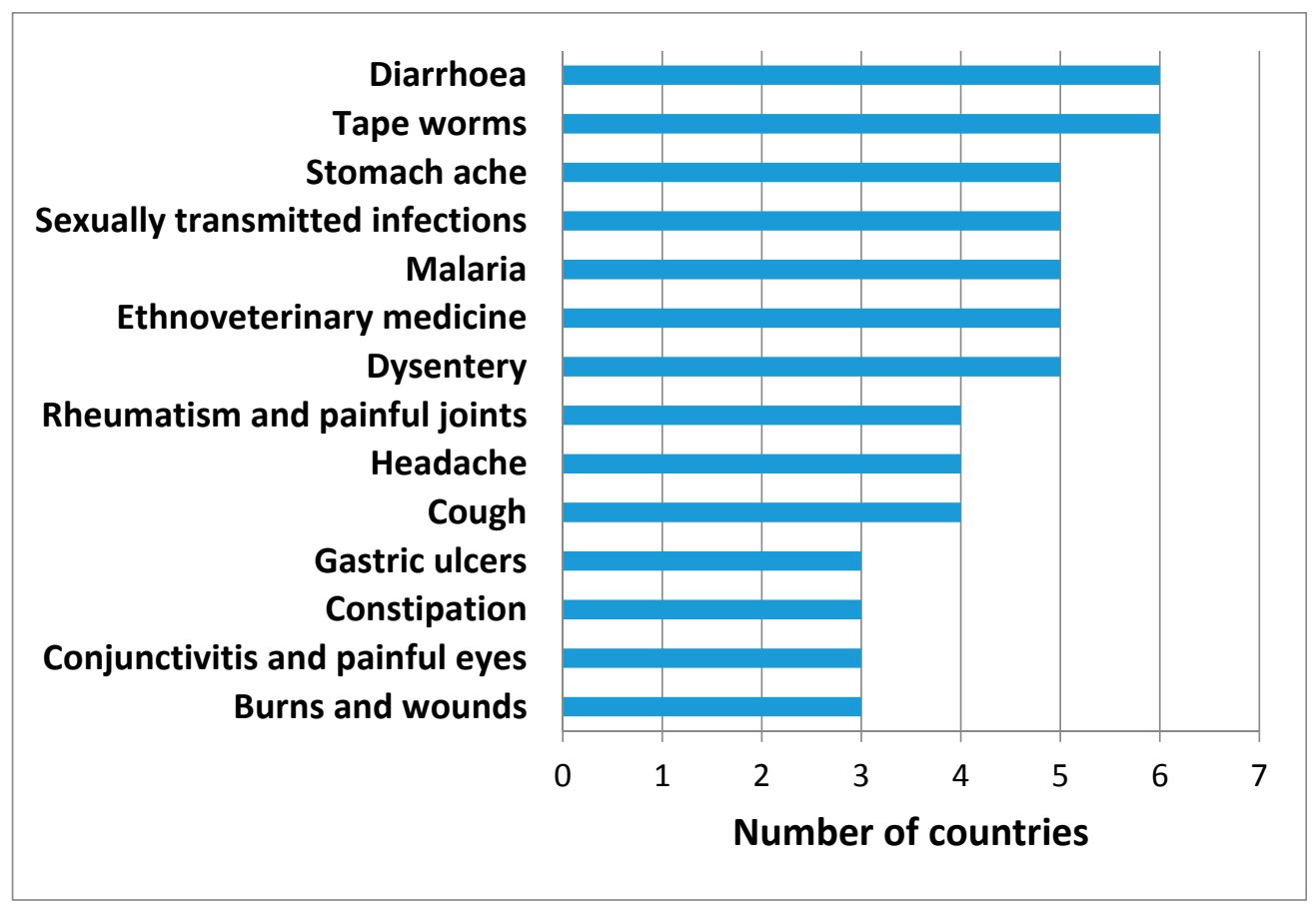

Figure 2. Cross-Cultural agreement among ethnomedicinal uses of B. micrantha in three or more countries in the tropics.

\section{Phytochemical Constituents of B. micrantha}

Multiple classes of phytochemicals including alkaloids, anthocyanidin, anthraquinones, carbohydrates, cyanogenic glycoside, essential oil, ester, flavonoids, oxalate, phenolic compounds, saponins, sterols, tannins, terpenoids as well as several minerals have been isolated from the bark, fruits, leaves and roots of $B$. micrantha $[4,36,46,69-77]$. Bark, fruits and leaves of $B$. micrantha contain a wide variety of classic nutrients, such as minerals, carbohydrates, polyol (hexahydroxy alcohol), and proteins (Table 2). Several chemical elements such as calcium, chromium, cobalt, copper, iron, lead, magnesium, manganese, nickel, phosphorus, potassium, sodium and zinc have been isolated from B. micrantha fruits (Table 2). Shelembe [46] found that the concentrations of elements in the fruits of B. micrantha were in the decreasing order of $\mathrm{Mg}>\mathrm{Ca}>\mathrm{Mn}>\mathrm{Zn}>\mathrm{Fe}>\mathrm{Cu}>\mathrm{Co}>\mathrm{Ni} \approx \mathrm{Cr}>\mathrm{Pb}$. The dietary reference intake (DRI) of some of the chemical elements is shown in Table 2 based on the FAO or WHO recommended dietary allowance (RDA) and tolerable upper levels (UL) [46]. Most major elements such as $\mathrm{Mg}, \mathrm{Ca}, \mathrm{K}$ and $\mathrm{Na}$, and heavy metals such as $\mathrm{Mn}, \mathrm{Zn}, \mathrm{Fe}, \mathrm{Cu}$ and $\mathrm{Cr}$ as determined by Shelembe [46] are within the permissible limit defined by FAO/WHO.

Table 2. Nutritional composition of B. micrantha bark, fruits and leaves.

\begin{tabular}{|c|c|c|c|c|}
\hline Nutritional Composition & Values & \multicolumn{2}{|c|}{ Dietary Reference Intake (DRI) (mg/day) } & References \\
\hline Carbohydrate & $1.7 \mathrm{~g} / 100 \mathrm{~g}$ & - & - & [46] \\
\hline $\mathrm{Ca}$ & $543 \mu \mathrm{g} \mathrm{g}^{-1}$ & $1000-1300$ & 2500 & [46] \\
\hline Co & $6.8 \mu \mathrm{g} \mathrm{g}^{-1}$ & - & - & [46] \\
\hline Cyanogenic glycosides & $810 \mathrm{mg} / 100 \mathrm{~g}$ & - & - & [73] \\
\hline $\mathrm{Fe}$ & $166 \mu \mathrm{g} \mathrm{g}^{-1}$ & $8-15$ & 45.0 & [46] \\
\hline K & $87.94 \mathrm{mg} / 100 \mathrm{~g}$ & 3000 & 3000 & [72] \\
\hline $\mathrm{Mg}$ & $859 \mu \mathrm{g} \mathrm{g}^{-1}$ & $310-320$ & 350 & [46] \\
\hline $\mathrm{Mn}$ & $414 \mathrm{\mu g} \mathrm{g}^{-1}$ & $1.6-3.0$ & 9.0 & [46] \\
\hline
\end{tabular}


Table 2. Cont.

\begin{tabular}{|c|c|c|c|c|}
\hline \multirow[b]{2}{*}{ Nutritional Composition } & \multirow[b]{2}{*}{ Values } & \multicolumn{2}{|c|}{ Dietary Reference Intake (DRI) (mg/day) } & \multirow[b]{2}{*}{ References } \\
\hline & & $\begin{array}{l}\text { Recommended Dietary } \\
\text { Allowance (RDA) }\end{array}$ & $\begin{array}{c}\text { Tolerable Upper Intake } \\
\text { Level (UL) }\end{array}$ & \\
\hline Moisture content & $90.1 \pm 0.60 \mathrm{~g} / 100 \mathrm{~g}$ & - & - & [46] \\
\hline $\mathrm{Na}$ & $254.8 \mathrm{mg} / 100 \mathrm{~g}$ & 2300 & 2300 & [72] \\
\hline $\mathrm{Ni}$ & $3 \mu \mathrm{g} \mathrm{g}^{-1}$ & - & - & [46] \\
\hline Oil & $0.9 \pm 0.01 \mathrm{~g} / 100 \mathrm{~g}$ & - & - & [46] \\
\hline Oxalate & $5.84 \mathrm{~g} / 100 \mathrm{~g}$ & - & - & $\begin{array}{l}{[40]} \\
{[73]}\end{array}$ \\
\hline $\mathrm{P}$ & $2545.4 \mathrm{mg} / 100 \mathrm{~g}$ & - & - & [72] \\
\hline $\mathrm{Pb}$ & $1{\mu g^{-1}}^{-1}$ & - & - & [46] \\
\hline Phytic acid & $0.5 \%$ & - & - & [72] \\
\hline Protein & $4.1 \pm 0.13 \mathrm{~g} / 100 \mathrm{~g}$ & - & - & [46] \\
\hline Saponin & $10.6 \%$ & - & - & [73] \\
\hline Tannin & $1160 \mathrm{mg} / 100 \mathrm{~g}$ & - & - & [73] \\
\hline $\mathrm{Zn}$ & $226 \mu^{-1} g^{-1}$ & $8-11$ & 34.0 & [46] \\
\hline
\end{tabular}

Pegel and Rogers [69] isolated delphinidin, ellagic acid, epifriedelinol, friedeline, gallic acid, taraxerole and taraxerone from stem bark and caffeic acid from the leaves of B. micrantha (Table 3). Twenty four essential oils were isolated from B. micrantha stem bark by Green et al. [78] (Table 3). Akinyeye and Olatunya [72] isolated phytic acid from the bark of B. micrantha (Table 3). Shelembe [46] isolated cycloartenol, cycloartenol acetate, ergosterol, stigmast-8(14)-en-3-ol, and 5 $\beta, 6 \beta$-epoxy-7-bromocholestan-3-one from fruits and acacic acid lactone, quercetin, quercetin-3-O-glucoside, oleanolic acid from the stem bark and leaves of B. micrantha (Table 3). Similarly, Shelembe et al. [77] isolated quercetin, quercetin-3-O-glucoside, oleanolic acid and acacic acid lactone from the stem bark and leaves while cycloartenol, cycloartenol acetate, ergosterol and stigmast-8(14)-en-3-ol were isolated from fruits of B. micrantha (Table 3).

Munayi [26] isolated trans-triacontyl-4-hydroxy-3-methoxyxinnamte, betulinic acid, catechin and friedelin from the stem bark of B. micrantha (Table 3). Some of these compounds, particularly alkaloids, essential oils, flavonoids, phenolics and tannins could be responsible for some of the ethnomedicinal uses of B. micrantha listed in Table 1 .

Table 3. Phytochemical compounds isolated from the bark, leaves and fruits of B. micrantha.

\begin{tabular}{|c|c|c|c|}
\hline Phytochemical Compounds & Plant Parts & Method of Compound Characterization & References \\
\hline \multicolumn{4}{|l|}{ Alkaloid } \\
\hline Stigmast-8(14)-en-3-ol & Fruits & Gas chromatography-mass spectrometry (GC-MC) & {$[46,77]$} \\
\hline \multicolumn{4}{|l|}{ Anthocyanidin } \\
\hline Delphinidin & Bark & Thin-Layer chromatography (TLC) & [69] \\
\hline \multicolumn{4}{|l|}{ Essential oil } \\
\hline N(ß)-Benzyl-14-(carboxymethyl) & Bark & GC-MS & [78] \\
\hline Benzene, 1.3-bis (3-phenoxyphenoxy) & Bark & GC-MS & [78] \\
\hline 2-Phenyl-2-tipyl-acenapthenone & Bark & GC-MS & [78] \\
\hline$\alpha$-Pinene & Bark & GC-MS & [78] \\
\hline Camphene & Bark & GC-MS & [78] \\
\hline 1,8-Cineole & Bark & GC-MS & [78] \\
\hline Camphor & Bark & GC-MS & [78] \\
\hline endo-Borneol & Bark & GC-MS & [78] \\
\hline Linalool & Bark & GC-MS & [78] \\
\hline 1- $\alpha$-Terpineol & Bark & GC-MS & [78] \\
\hline$\alpha$-Caryophyllene oxide & Bark & GC-MS & [78] \\
\hline Nopol & Bark & GC-MS & [78] \\
\hline 2-Pinen-4-one & Bark & GC-MS & [78] \\
\hline$(-)-$ Bornyl acetate & Bark & GC-MS & [78] \\
\hline 1-Tetradecanol (fatty alcohol) & Bark & GC-MS & [78] \\
\hline 5-Octadecene & Bark & GC-MS & [78] \\
\hline Hexadecanoic acid methyl ester & Bark & GC-MS & [78] \\
\hline Palmitic acid & Bark & GC-MS & [78] \\
\hline 17-Pentatriacontene & Bark & GC-MS & [78] \\
\hline Tritetracontane & Bark & GC-MS & [78] \\
\hline $5 \beta$-Pregn-11-ene & Bark & GC-MS & [78] \\
\hline 4-Imidozolidinone & Bark & GC-MS & [78] \\
\hline Naphthalene & Bark & GC-MS & [78] \\
\hline Quinoline & Bark & GC-MS & [78] \\
\hline
\end{tabular}


Table 3. Cont.

\begin{tabular}{|c|c|c|c|}
\hline Phytochemical Compounds & Plant Parts & Method of Compound Characterization & References \\
\hline \multicolumn{4}{|l|}{ Flavonoids } \\
\hline Caffeic acid & Leaves & TLC & {$[69]$} \\
\hline Quercetin & Bark, leaves & GC-MC, nuclear magnetic resonance NMR & {$[46,77]$} \\
\hline Quercetin-3-O-glucoside & Bark, leaves & GC-MC, NMR & {$[46,77]$} \\
\hline \multicolumn{4}{|l|}{ Phenolic } \\
\hline trans-Triacontyl-4-hydroxy-3-methoxyci & amatßark & NMR & [26] \\
\hline \multicolumn{4}{|l|}{ Polyol } \\
\hline Phytic acid & Bark & & {$[72]$} \\
\hline \multicolumn{4}{|l|}{ Sterols } \\
\hline Ergosterol & Fruits & GC-MC & {$[46,77]$} \\
\hline $5 \beta, 6 \beta$-Epoxy-7-bromocholestan-3-one & Fruits & GC-MC & [46] \\
\hline \multicolumn{4}{|l|}{ Tannins } \\
\hline Ellagic acid & Bark & TLC & [69] \\
\hline Gallic acid & Bark & TLC & [69] \\
\hline \multicolumn{4}{|l|}{ Triterpenes } \\
\hline Acacic acid lactone & Bark, leaves & GC-MC, NMR & {$[46,77]$} \\
\hline Betulinic acid & Bark & NMR & {$[26]$} \\
\hline Catechin & Bark & NMR & {$[26]$} \\
\hline Cycloartenol & Fruits & GC-MC & {$[46,77]$} \\
\hline Cycloartenol acetate & Fruits & GC-MC & {$[46,77]$} \\
\hline Epifriedelinol & Bark & TLC & {$[69]$} \\
\hline Friedeline & Bark & NMR, TLC & {$[26,69]$} \\
\hline Oleanolic acid & Bark, leaves & GC-MC, NMR & {$[46,77]$} \\
\hline Taraxerole & Bark & TLC & [69] \\
\hline Taraxerone & Bark & TLC & [69] \\
\hline
\end{tabular}

\section{Pharmacological Properties of B. micrantha}

The following activities have been reported from B. micrantha: anthelmintic [79], antibacterial [19,32,36,74,80-83], anticonvulsant and sedative [84], antidiabetic [85], antidiarrhoeal [25], antifungial [36,83], anti-Helicobacter pylori [70,81,82], antimycobacterial [78,86], antinociceptive [87], antioxidant [77,85,87-89], antiplasmodial [59,90,91], antischistosomal [92], antiviral [39,40], hepatoprotective [88], insecticidal [93], $\beta$-lactamase inhibitory [94], toxicity and cytotoxicity [87,95-99].

\subsection{Anthelmintic}

Waterman et al. [79] evaluated the anthelmintic activities of aqueous and organic bark extract of $B$. micrantha using a standard motility assay against a levamisole resistant strain of the nematode Caenorhabditis elegans. The degree of activity of extracts was presented as average percentage of worm death and statistically compared to a negative control. B. micrantha aqueous and organic bark extracts showed $89.4 \%$ and $80.7 \%$ dead worms higher than the negative control [79]. These anthelmintic evaluations are of importance in the traditional use of B. micrantha against tape worms in Cameroon [32], Ghana [34], Kenya [38,60], Nigeria [41], South Africa [2,25], Tanzania [9] and Uganda [15] and will also play an important role in future research focusing on control and management of worm infections in sub-Saharan Africa.

\subsection{Antibacterial}

Samie et al. [80] evaluated the antibacterial activities of B. micrantha methanol, acetone and hexane bark, roots and seeds extracts against Aeromonas hydrophila, Bacillus cereus, Bacillus pumilus, Bacillus subtilis, Enterobacter cloacae, Enterococcus fecalis, Escherichia coli, Klebsiella pneumoniae, Pantoea agglomerans, Proteus mirabilis, Pseudomonas aeruginosa, Salmonella cholerae-suis, Serratia marcescens, Staphylococcus aureus and Shigella flexneri using the disc diffusion and the micro-dilution methods. The extracts of the bark, roots and seeds of B. micrantha gave diameter of zone of inhibition ranging from 8-14 mm against all pathogenic organisms except K. pneumoniae and S. cholerae-suis [80]. The minimal inhibitory concentration (MIC) values of methanol, acetone and hexane bark, roots and seeds extracts 
against the tested bacteria were within the range of $1.5 \mathrm{mg} / \mathrm{mL}$ to $>12 \mathrm{mg} / \mathrm{mL}$ [80]. Similarly, Steenkamp et al. [19] evaluated antibacterial activities of methanol bark extract of $B$. micrantha against E. coli, P. aeruginosa, S. aureus and Staphylococcus epidermidis using the plate-hole diffusion and broth micro-dilution methods. None of the extracts showed activity against E. coli and P. aeruginosa while MIC values between $1.25 \mathrm{mg} / \mathrm{mL}$ and $5.00 \mathrm{mg} / \mathrm{mL}$ were obtained against S. aureus and S. epidermidis [19]. Gangoué-Piéboji et al. [32] evaluated the antibacterial activities of B. micrantha methanol stem bark extracts against clinically proved beta-lactam-resistant bacteria Acinetobacter baumannii, Enterobacter aerogenes, E. cloacae, Enterococcus hirae, Enterococcus spp., E. coli, Klebsiella oxytoca, K. pneumoniae, $P$. aeruginosa, $S$. marcescens and $S$. aureus by using disc-diffusion and agar-dilution assays. The methanol extracts demonstrated broad spectrum activity against all bacteria tested with inhibition zones in the range of 14-27 $\mathrm{mm}$. The MIC values of methanol extracts against the tested bacteria were found to range from $1.25 \mathrm{mg} / \mathrm{mL}$ to $10 \mathrm{mg} / \mathrm{mL}$ [32]. Adefuye et al. [81] evaluated antibacterial activities of B. micrantha dichloromethane, ethyl acetate, acetone, ethanol, methanol and methanol hydroxide stem bark extracts against Salmonella typhimurium, Shigella sonnei and S. aureus using agar-well diffusion method with ciprofloxacin as control. Zone diameters of inhibition ranged from 0 to $28 \mathrm{~mm}$ for the six extracts and 29 to $38 \mathrm{~mm}$ for ciprofloxacin. The $\mathrm{MIC}_{50}$ values ranged from $0.078 \mathrm{mg} / \mathrm{mL}$ to $1.25 \mathrm{mg} / \mathrm{mL}$ [81]. Mabeku et al. [36] evaluated the antibacterial activities of methanol, ethanol, hexane, ethyl acetate, aqueous, mixture of methanol and water, and mixture of ethanol and water stem bark extracts of B. micrantha against B. cereus, Citrobacter freundii, E. cloacae, E. coli, K. pneumoniae, Morganella morganii, P. agglomerans, Proteus vulgaris, P. mirabilis, P. aeruginosa, Salmonella typhi, Shigella dysenteriae, S. flexneri, S. aureus and Streptococcus feacalis using the disc diffusion assay and broth micro-dilution methods. The best antibacterial activity was demonstrated against $S$. typhi with MIC value of $50 \mu \mathrm{g} / \mathrm{mL}$ and minimal bactericidal concentration $(\mathrm{MBC})$ value of $400 \mu \mathrm{g} / \mathrm{mL}$ [36]. In a different study, Adefuye and Ndip [82] evaluated antibacterial activities of ethyl acetate extract of stem bark of B. micrantha against $S$. typhimurium, $S$. sonnei and $S$. aureus with ciprofloxacin as a positive control. The MIC 50 values ranged from $0.0048 \mathrm{mg} / \mathrm{mL}$ to $0.312 \mathrm{mg} / \mathrm{mL}$ [82]. Traore et al. [83] evaluated antibacterial activities of methanolic stem bark extracts of B. micrantha against E. coli, Mycobacterium chelonae and $S$. aureus. The methanolic extract of $B$. micrantha demonstrated weak activity against $E$. coli with $\mathrm{IC}_{50}$ values of $64 \mu \mathrm{g} / \mathrm{mL}$ [83]. Douglas and Gitonga [74] evaluated antibacterial activities of methanol and ethyl acetate leaf extracts of B. micrantha against E. coli, S. typhi and S. aureus using micro-broth dilution assay. Methanol extract of $B$. micrantha exhibited a zone of inhibition of 7 to $19 \mathrm{~mm}$ against S. aureus and S. typhi respectively [74]. These documented antibacterial properties of B. micrantha corroborate the traditional uses of the species against bacterial infections such as cough in Cameroon, DRC, Nigeria and Zimbabwe [16,18,21,22,28,32,33], diarrhoea in Cameroon, DRC, Kenya, Nigeria, South Africa and Tanzania [2,9,16,22,25,32,36,38-41], dysentery in Burundi, Cameroon, DRC, Gambia and Nigeria [16,33,36,42,43], sexually transmitted diseases in Guinea-Bissau and Kenya [47,60,63], stomach ache in Guinea-Bissau, Kenya, Nigeria, South Africa and Tanzania [38,41,47,48,51,60], syphilis in Sierra Leone and Uganda [61,65] and venereal diseases in Kenya and South Africa [2,23,25,38].

\subsection{Anticonvulsant and Sedative}

Bum et al. [84] evaluated the anticonvulsant effects of crude stem bark extracts of B. micrantha using mice model maximal electroshock (MES), strychnine (STR), pentylenetetrazol (PTZ), picrotoxin (PIC), isonicotinic hydrazide acid (INH)-induced convulsions and diazepam-induced sleep in assessing the sedative effects. Results showed that $B$. micrantha stem bark extracts at the doses of 34 and $67 \mathrm{mg} / \mathrm{kg}$ protected $100 \%, 80 \%, 80 \%$ and $80 \%$ of mice from PIC, STR, PTZ and MES-induced seizures, respectively [84]. B. micrantha also delayed the onset to seizures in the INH test. The decoctions of B. micrantha possess sedative and anticonvulsant activities and these results corroborate the use of the species as herbal medicine for epilepsy and insomnia in Cameroon [55]. 


\subsection{Antidiabetic}

Adika et al. [85] evaluated the antidiabetic activities of methanol leaf extract of B. micrantha using alloxan-induced diabetic mice in vivo and in vitro. The methanol leaf extract at the dose of 250, 500, and $1500 \mathrm{mg} / \mathrm{kg}$ showed remarkable time-dependent decrease in blood glucose level in alloxan-induced diabetic mice. Adika et al. [85] found that there was no significant difference between the extract-treated groups and the groups treated with $10 \mathrm{mg} / \mathrm{kg}$ of distilled water and glibenclamide $(2 \mathrm{mg} / \mathrm{kg}$ ) respectively. Adika et al. [85] found that after six hours posttreatment, the blood glucose level for the groups treated with $250 \mathrm{mg} / \mathrm{kg}$ of $B$. micrantha and glibenclamide $(2 \mathrm{mg} / \mathrm{kg})$ were lower than the normal blood glucose level for the groups before the induction of diabetes. Even in its crude form, the effects were comparable to that of glibenclamide, an oral sulfonylurea with proven antidiabetic activity. These findings demonstrate that $B$. micrantha has antidiabetic effects on experimental model of diabetes in mice and validate its use in Cameroon, Guinea and Nigeria as a traditional medicine for the treatment of diabetes mellitus [34-37]. This finding suggests that the leaf extract could be a potential source of a novel antidiabetic for the management of diabetes mellitus.

\subsection{Antidiarrhoeal}

Lin et al. [25] evaluated anti-diarrhoeal activities of aqueous and methanolic bark extract of B. micrantha against different experimental models of diarrhoea in rats as well as bacteria that cause diarrhoea such as E. coli, Plesiomonas shigelloides, Salmonella virchow and S. dysenteriae and S. flexneri. The methanolic bark extract of B. micrantha demonstrated weak inhibitory activities against $P$. shigelloides and S. flexneri [25]. Based on the results in experimental rat models, there were significant reductions in faecal output and frequency of droppings when plant extracts were administered compared with castor-oil treated rats [25]. All plant extracts also significantly retarded the propulsion of charcoal meal and significantly inhibited the PGE(2)-induced enteropooling [25]. These findings by Lin et al. [25] corroborate the species' antidiarrhoeal potential and its traditional use in the treatment of diarrhoea, dysentery and other gastro-intestinal problems in Burundi [43], Cameroon [21,32,46], DRC [16,22], Gambia [42], Guinea-Bissau [47,48], Kenya [38,60], Nigeria [33,41], South Africa $[2,25,39,40]$ and Tanzania $[9,51]$.

\subsection{Antifungal}

Mabeku et al. [36] evaluated the antifungal activities of methanol, ethanol, hexane, ethyl acetate, aqueous, mixture of methanol and water, and mixture of ethanol and water stem bark extracts of B. micrantha against Candida albicans and Candida glabrata using the disc diffusion assay and broth micro-dilution methods. The ethanol extract of stem bark of B. micrantha gave a diameter zone of inhibition of $10 \mathrm{~mm}$ against C. glabrata [36]. Similarly, Traore et al. [83] evaluated antifungal activities of methanolic stem bark extracts of B. micrantha against Aspergillus fumigatus, C. albicans and Trichophyton rubrum. Traore et al. [83] used the following arbitrary scale in assessing the level of antimicrobial activity: strong $\left(\mathrm{IC}_{50} \leq 10 \mu \mathrm{g} / \mathrm{mL}\right)$, good $\left(10 \mu \mathrm{g} / \mathrm{mL}<\mathrm{IC}_{50} \leq 20 \mu \mathrm{g} / \mathrm{mL}\right)$, moderate $(20$ $\left.\mu \mathrm{g} / \mathrm{mL}<\mathrm{IC}_{50} \leq 40 \mu \mathrm{g} / \mathrm{mL}\right)$, weak $\left(40 \mu \mathrm{g} / \mathrm{mL}<\mathrm{IC}_{50} \leq 64 \mu \mathrm{g} / \mathrm{mL}\right)$ and inactive $\left(\mathrm{IC}_{50} \geq 64 \mu \mathrm{g} / \mathrm{mL}\right)$. The methanolic extract of $B$. micrantha demonstrated weak activity against $A$. fumigatus with $\mathrm{IC}_{50}$ value of $64 \mu \mathrm{g} / \mathrm{mL}$ [83]. These documented antifungal properties correlate with traditional applications of B. micrantha against various skin infections in Cameroon [29], Kenya [62] and Tanzania [51].

\subsection{Anti-Helicobacter pylori}

Adefuye et al. [81] evaluated anti-Helicobacter pylori activities of B. micrantha dichloromethane, ethyl acetate, acetone, ethanol, methanol and 40\% methanol hydroxide stem bark extracts against Helicobacter pylori using agar-well diffusion method with ciprofloxacin as control. Zone diameters of inhibition ranged from 0 to $18 \mathrm{~mm}$ for the extract and 29 to $38 \mathrm{~mm}$ for ciprofloxacin. The $\mathrm{MIC}_{50}$ values ranged from $0.312 \mathrm{mg} / \mathrm{mL}$ to $0.625 \mathrm{mg} / \mathrm{mL}$ [81]. Okeleye et al. [70] evaluated anti-Helicobacter pylori 
activities of ethyl acetate, acetone, aqueous and methanol extracts of stem bark of $B$. micrantha against Helicobacter pylori using clarithromycin, metronidazole and amoxicillin as controls. The inhibition zone diameters ranged from 0-23 mm for all the extracts in comparison to 0-35 mm observed for clarithromycin [70]. Marked susceptibility of H. pylori strains (100\%) was observed for the acetone extract, followed by ethyl acetate extract at 93.5\% and clarithromycin had susceptibility of 58.1\% [70]. The $\mathrm{MIC}_{50}$ values ranged from 0.0048 to $0.313 \mathrm{mg} / \mathrm{mL}$ while the $\mathrm{MIC}_{90}$ values ranged from 0.0048 to $2.5 \mathrm{mg} / \mathrm{mL}$ for the acetone and ethyl acetate extracts [70]. Adefuye and Ndip [82] evaluated anti-Helicobacter pylori activities of ethyl acetate extract of stem bark of $B$. micrantha against $H$. pylori with ciprofloxacin as positive control. B. micrantha extracts showed some activity with $\mathrm{MIC}_{50}$ values ranging from $1.25 \mathrm{mg} / \mathrm{mL}$ to $5.0 \mathrm{mg} / \mathrm{mL}$ [82]. The ethyl acetate extract could thus be a potential source of lead molecules for the design of new anti-Helicobacter pylori therapies. These findings are significant since bark, leaf and root decoctions of $B$. micrantha are widely used as traditional remedies for gastric ulcers in Cameroon [32], DRC [16] and South Africa [46].

\subsection{Antimycobacterial}

Green et al. [86] evaluated the antimycobacterial activities of acetone, methanol, hexane and ethanol leaf extracts of $B$. micrantha against Mycobacterium tuberculosis using a tetrazolium microplate assay to determine the minimum inhibitory concentration (MIC). Acetone extract was active against M. tuberculosis with a MIC value of $25 \mu \mathrm{g} / \mathrm{mL}$ [86]. In another study, Green et al. [78] evaluated the antimycobacterial activities of the $n$-hexane sub-fraction of ethyl acetate fractions from acetone extracts of $B$. micrantha stem barks using the resazurin microplate assay against $M$. tuberculosis. The $n$-hexane fraction showed 20\% inhibition of M. tuberculosis H37Ra and almost 35\% inhibition of M. tuberculosis isolate resistant to all first-line drugs at $10 \mu \mathrm{g} / \mathrm{mL}$ [78]. The primary ethyl acetate fraction showed MIC value of $8.25 \mu \mathrm{g} / \mathrm{mL}$ against H37Ra M. tuberculosis strain [78]. The fraction also inhibited the growth of $M$. tuberculosis isolate resistant to isoniazid (INH), ethambutol (EMB), streptomycin (STM) and rifampicin (RIF) at a concentration of $50 \mu \mathrm{g} / \mathrm{mL}$ [78]. These preliminary evaluations done by Green et al. [78,86] serve as scientific validation for the use of B. micrantha in traditional medicine for treatment of respiratory systems such as chest complaints and cough in Cameroon $[21,28,32]$, DRC [16,22], Nigeria [33] and Zimbabwe [18].

\subsection{Antinociceptive}

Onoja et al. [87] evaluated the antinociceptive effects of the hydromethanolic extract of $B$. micrantha stem bark. The antinociceptive effects of B. micrantha extracts at the doses of 50, $100 \mathrm{and} 200 \mathrm{mg} / \mathrm{kg}$ were investigated using male Wistar rats via acetic acid-induced writhing reflex and tail flick methods and the effects of B. micrantha on thiopentone-induced narcosis was also investigated. The B. micrantha extracts produced a significant dose-dependent decrease in the mean number of abdominal constriction in the acetic acid-induced writhing reflex when compared to the negative control. Both the extract $(200 \mathrm{mg} / \mathrm{kg}$ ) and paracetamol (400 mg/ kg) produced $61.85 \%$ and $73.08 \%$ inhibition of writhing reflex, respectively [87]. B. micrantha and pentazocine $(3 \mathrm{mg} / \mathrm{kg})$ caused a significant increase in the pain reaction time (PRT) in treated rats when compared to the negative control group in tail flick method. The pretreatment of the rats with $B$. micrantha at different doses increased the normal sleeping time of thiopentone from $69.33 \pm 7.31 \mathrm{~min}$ to an average of $105.33 \pm 11.88 \mathrm{~min}$ [87]. The results of the effect of the extract on acetic acid-induced writhing reflex suggest that the extract may have a peripheral pain relieving effect mediated through the inhibition of cyclooxygenase and prostaglandin synthesis. These findings support the traditional use of B. micrantha in the management of pain, for example as remedy for abdomninal pain in DRC and Uganda [15,16], epigastric pain and sore eyes in Tanzania [45], muscle pain in Cameroon [55], painful eyes, joints and as pain killer in South Africa [2,23,25,39,46,54] and wounds in DRC, Sierra Leone and South Africa $[2,16,23-25,65]$. 


\subsection{Antioxidant}

Nwaehujor and Udeh [88] evaluated the antioxidant activities of the methanolic leaf extracts of $B$. micrantha using the DPPH (2,2-diphenyl-1-picrylhydrazyl) and ferric reducing antioxidant power (FRAP) assay methods. The DPPH assay showed 98\% antioxidant activity at concentration of $400 \mu \mathrm{g} / \mathrm{mL}$ while FRAP values were 0.016, 0.39, 0.455, 0.601 and $1.382 \mu \mathrm{M}$ at 10, 50, 100, 200 and $400 \mu \mathrm{g} / \mathrm{mL}$ respectively [88]. Adika et al. [85] evaluated antioxidant activities of methanol leaf extracts of B. micrantha using DPPH spectrophotometric assay at the concentration of $400 \mu \mathrm{g} / \mathrm{mL}$. The ferric reducing antioxidant power showed a significant concentration-dependent increase in the total antioxidant power. Nwaehujor et al. [89] evaluated antioxidant activities of the methanolic leaf extracts of $B$. micrantha using the DPPH and FRAP assay methods with ascorbic acid as reference standard. The methanol extracts of $B$. micrantha leaves gave $98 \%$ antioxidant activity at a maximal test concentration of $400 \mu \mathrm{g} / \mathrm{mL}$ while ascorbic acid produced a comparatively reduced percentage value of $79 \%$ at the same concentration [89]. In the FRAP assay, B. micrantha leaf extracts produced $1.39 \mu \mathrm{M}$ at $400 \mu \mathrm{g} / \mathrm{mL}$ but $1000 \mu \mathrm{g} / \mathrm{mL}$ of ascorbic acid had a standard FRAP value of $2.0 \mu \mathrm{M}$ [89]. Onoja et al. [87] evaluated the antioxidant activities of the hydromethanolic extract of B. micrantha stem bark using 2,2-diphenyl-1-picrylhydrazyl (DPPH) photometric assay. B. micrantha extract produced concentration-dependent increase in percentage antioxidant activity in DPPH photometric assay. The $B$. micrantha extract demonstrated a potent antioxidant activities with $50 \%$ inhibitory concentration $\left(\mathrm{IC}_{50}\right)$ of $<25 \mu \mathrm{g} / \mathrm{mL}$ concentration in DPPH photometric assay [87]. These results suggest that B. micrantha has antioxidant potential. Shelembe et al. [77] evaluated the antioxidant activities of fruit methanol extracts of $B$. micrantha using the DPPH stable free radical method using ascorbic acid as control. The $\mathrm{IC}_{50}$ value for the methanol extract of the stem bark of B. micrantha was $150 \mu \mathrm{g} / \mathrm{mL}$ while that of the standard ascorbic acid was $41 \mu \mathrm{g} / \mathrm{mL}$ indicating the high antioxidant potential of the plant, especially the stem bark [77]. The scavenging effect of fruit extract increased with increasing concentrations, with the extract exhibiting appreciable scavenging activity at $1000 \mu \mathrm{g} \mathrm{mL}^{-1}$ with the scavenging ability $85.5 \%$ [77]. These antioxidant activities are probably due the presence of flavonoids and phenolic compounds [100].

\subsection{Antiplasmodial}

Clarkson et al. [90] evaluated antiplasmodial activities of B. micrantha aqueous, dichloromethane, dichloromethane and methanol (1:1) twig extracts against Plasmodium falciparum using the parasite lactate dehydrogenase $(\mathrm{pLDH})$ assay. B. micrantha dichloromethane and methanol (1:1) extract showed a weak activity with $\mathrm{IC}_{50}$ value of $59.3 \mu \mathrm{g} / \mathrm{mL}$ [90]. Similarly, Ajaiyeoba et al. [91] evaluated antiplasmodial activities of B. micrantha methanol leaf extracts against P. falciparum using the lactate dehydrogenase $(\mathrm{pLDH})$ assay. B. micrantha extract showed a weak activity with $\mathrm{IC}_{50}$ value of $158.7 \mu \mathrm{g} / \mathrm{mL}$ [91]. Nondo et al. [59] evaluated antiplasmodial activities of B. micrantha stem bark ethanol extracts against chloroquine-resitant $P$. falciparum strain using the parasite lactase dehydrogenase method. B. micrantha extracts inhibited malaria parasite by $71.87 \%$ growth inhibition rate at $100 \mu \mathrm{g} / \mathrm{mL}$ on $P$. falciparum strain. Although $B$. micrantha extracts are characterized by weak antiplasmodial activities $[59,90,91]$, these results provide compelling evidence for the rationale of the species as malaria remedy in Guinea [57], Ivory Coast [58], Kenya [56] and Tanzania [20,59].

\subsection{Antischistosomal}

Waiganjo et al. [92] evaluated the antischistosomal activities of hexane, methanol and water extract of B. micrantha bark on Swiss white mice infected with Schistosoma mansoni with praziquantel as control. There were no significant differences between praziquantel which showed worm reduction percentages of $75.2 \%$ against $48.7 \%$ and $63.4 \%$ demonstrated by hexane and water extracts respectively [92]. These findings demonstrated that $B$. micrantha extracts were able to protect the mice from schistosomiasis infection. 


\subsection{Antiviral}

Bessong et al. [39] evaluated B. micrantha leaf methanol extracts against human immunodeficiency type 1 reverse transcriptase by assessing inhibition of the RNA dependent DNA polymerase activity by measuring the degree of incorporation of methyl-3H thymidine triphosphate using polyadenylic acid. Ribonuclease $\mathrm{H}$ activity was evaluated by measuring the extent of degradation of a radiolabelled RNA in an RNA/DNA hybrid by reverse transcriptase. The methanol extract of the leaves of $B$. micrantha inhibited the polymerase with $\mathrm{IC}_{50}$ value of $23.5 \mu \mathrm{g} / \mathrm{mL}$ and the ribonuclease $\mathrm{H}$ with $\mathrm{IC}_{50}$ value of $18.9 \mu \mathrm{g} / \mathrm{mL}$ [39]. In another study, Bessong et al. [40] evaluated antiviral activities of B. micrantha root methanol extracts for activity against HIV-1 reverse transcriptase (RT) and integrase (IN). The $n$-butanol fraction obtained from the crude methanol extracts of $B$. micrantha inhibited the RNA-dependent-DNA polymerization (RDDP) activity of HIV-1 RT with an $\mathrm{IC}_{50}$ of $7.3 \mu \mathrm{g} / \mathrm{mL}$. More pharmacological evaluations are required as $B$. micrantha is widely used against viral infections such as HIV/AIDs in Kenya [52], yellow fever in Tanzania [20] and other infectious diseases such as diarrhoea, dysentery, sexually transmitted infections (STIs) and skin infections.

\subsection{Hepatoprotective}

Nwaehujor and Udeh [88] evaluated hepatoprotective activities of the methanolic leaf extracts of $B$. micrantha on paracetamol induced liver damage in Wistar rats through measuring alanine aminotransaminase (ALT), aspartate aminotransferase (AST), alkaline phosphate (ALP), bilirubin and total protein. B. micrantha extract significantly decreased the level of AST in the rats given PCM, reduced ALP and total bilirubin while total protein was significantly increased [88]. Nwaehujor and Udeh [88] also found that the ethyl acetate extract of B. micrantha had better hepatoprotective effects on the Wistar rats than the known silymarin especially at $300 \mathrm{mg} / \mathrm{kg}$. Therefore, B. micrantha has the ability to help in the regeneration of damaged hepatic cells and can be useful in the treatment and management of hepatic diseases.

\subsection{Insecticidal}

Adesina et al. [93] evaluated the insecticidal activities of aqueous leaf extracts of B. micrantha against Podagrica uniforma (Jacoby) and Nisotra dilecta (Jacoby) insect pests of okra (Abelmoschus esculentus (L.) Moench) with synthetic insecticide cypermethrin as control. Yield parameters such as number of fruits and fruit weight were collected on insect population before treatment application and three days after spraying of insecticides at 28, 35, 42, 56 days after planting (DAP). There were no significant differences between mean number of $P$. uniforma and $N$. dilecta counted on okra plants after 56 DAP which were $0.80 \pm 0.10$ and $0.47 \pm 0.17$ for B. micrantha and cypermethrin respectively. There were no significant differences in mean yield of okra fruits after application of $B$. micrantha and cypermethrin which stood at $0.93 \pm 0.3$ and $2.20 \pm 0.23$ respectively [93]. Results obtained showed that $B$. micrantha extracts exhibited effectiveness in reducing the insect population and improved A. esculentus fruit yield compared to cypermethrin. Therefore, B. micrantha crude extracts could be explored as promising insecticidal agents to provide valuable alternatives to chemical control of insect infestation on $A$. esculentus [93]. These findings indicate that $B$. micrantha has insecticidal properties corroborating traditional use of the bark and leaf decoction as insecticide in Tanzania [51].

\subsection{6. $\beta$-Lactamase Inhibitory}

Gangoué-Piéboji et al. [94] evaluated the anti- $\beta$-lactamase activities of methanolic stem bark extracts of B. micrantha by assessing the inhibition activities (over 90\%) against four classes of $\beta$-lactamases, namely TEM-1, OXA-10, IMP-1 and P99. B. micrantha extracts had strong inhibition activities of $99.2 \%$ and $92.0 \%$ against OXA-10 and P99 respectively. After elimination of tannins, the extracts of $B$. micrantha were tested further for anti- $\beta$-lactamase activities with OXA-10 demonstrating potent inhibitory activity with $50 \%$ inhibitory concentration $\left(\mathrm{IC}_{50}\right)$ value of $0.02 \mathrm{mg} / \mathrm{mL}$ [94]. Further 
research aimed at isolating and elucidating the chemical structure of the active constituents of B. micrantha will provide useful leads in the search and development of $\beta$-lactamase inhibitors.

\subsection{Toxicity and Cytotoxicity}

Ajaiyeoba et al. [95] reported the cytotoxicity effects of 20 plants used in Nigeria as antimalarials. The $50 \%$ lethal concentration ( $\mathrm{LC}_{50}$ value) at $95 \%$ confidence interval was calculated with the brine shrimp lethality assay for each plant methanol extract. B. micrantha leaf extract showed the least $\mathrm{LC}_{50}$ value of $>9.0 \times 10^{6} \mathrm{\mu g} / \mathrm{mL}$ [95]. Moshi et al. [97] evaluated toxicity of dichloromethane and/or ethanol root extracts of $B$. micrantha using brine shrimp toxicity with dimethyl sulphoxide (DMSO) and seawater as negative controls. B. micrantha ethanol root extract was found to be mildly toxic with concentration killing fifty percent of the larvae $\left(\mathrm{LC}_{50}\right)$ of $30 \mu \mathrm{g} / \mathrm{mL}$ [97]. Onoja et al. [87] assessed oral acute toxicity of hydromethanolic stem bark extract of $B$. micrantha using the OECD guideline, the up-and-down-procedure by orally dosing five male Wistar rats with $2000 \mathrm{mg} / \mathrm{kg}$ of B. micrantha and observing the rats for $48 \mathrm{~h}$ for signs of toxicity and death. Oral administration of the B. micrantha extract was well tolerated at the dose of $2000 \mathrm{mg} / \mathrm{kg}$ and no death and clinical signs of toxicity were observed [87]. Similarly, Osebe et al. [99] evaluated toxicity of water stem bark extract of B. micrantha using brine shrimp lethality test for the determination of $\mathrm{LC}_{50}$ and the water extract with $\mathrm{LC}_{50}$ of $77 \mu \mathrm{g} / \mathrm{mL}$ was deemed toxic.

Steenkamp et al. [96] evaluated the cytotoxicity of B. micrantha using human adenocarcinoma cells of the cervix (HeLa), human breast cells (MCF-12A), lymphocytes (both resting and stimulated) and primary porcine hepatocytes. Steenkamp et al. [96] also determined acute systemic toxicity of B. micrantha extracts using the luminescent bacteria Vibrio fischerii and the vertebrate Poecilia reticulata (guppy). The $50 \%$ inhibition of proliferation ( $\mathrm{IC}_{50}$ ) of B. micrantha in HeLa cells was $8.9 \mu \mathrm{g} / \mathrm{mL}, \mathrm{IC}_{50}$ was $24.2 \mu \mathrm{g} / \mathrm{mL}$ in MCF-12A cells and the positive control, cisplatin had IC 50 value of $1.14 \mu \mathrm{g} / \mathrm{mL}$ and $0.21 \mu \mathrm{g} / \mathrm{mL}$ for the HeLa and MCF-12A cells respectively. Toxicity was found to be concentration dependent when HeLa and MCF-12A cells were exposed to B. micrantha extracts. B. micrantha extracts resulted in 100\% mortality of the guppies [96]. Similarly, Omosa et al. [98] evaluated the cytotoxicity of dichloromethane and methanol (1:1) extract of $B$. micrantha leaves and stem bark using the resazurin reduction assay against CCRF-CEM leukemia cell line. The dichloromethane and methanol extract of $B$. micrantha leaves and stem bark displayed cytotoxicity towards leukemia CCRF-CEM cells with $\mathrm{IC}_{50}$ value of $9.43 \mu \mathrm{g} / \mathrm{mL}$ and $23.5 \mu \mathrm{g} / \mathrm{mL}$ respectively [98]. These studies show that $B$. micrantha extracts are cytotoxic and possess acute systemic toxicity. According to Verdcourt and Trump [101], B. micrantha is poisonous as death of a patient has been reported, four hours after the ingestion of a cough mixture made from B. micrantha herbal concoction in Kenya.

\section{Conclusions}

The historical traditional usage of $B$. micrantha as herbal medicine throughout its distribution range, the documented phytochemistry and pharmacological properties call for detailed pharmacokinetics and clinical research on the species and its pharmaceutical and food products. At the moment there is insufficient evidence to interpret the documented ethnomedicinal uses with specific chemical mechanisms associated with some of the documented pharmacological properties. Future research should identify the bioactive compounds, details of their molecular modes or mechanisms of action, pharmacokinetics and physiological pathways for specific bioactives of B. micrantha. B. micrantha has been categorized as poisonous by Verdcourt and Trump [101], toxicity and cytotoxicity studies conducted by Steenkamp [96], Moshi et al. [97], Omosa et al. [98] and Osebe et al. [99] appear to suggest that the species is toxic and may cause damage to genetic material and therefore, has potential to cause long-term damage in patients when administered as herbal medicines. There is need for rigorous toxicological and clinical studies aimed at identification of poisonous compounds, associated pharmacological activities and the side effects that are likely to be caused when B. micrantha is used as 
herbal medicine. Therefore, future research should focus on dosage range that is safe for humans and evaluation of target-organ toxicity.

Acknowledgments: Research reported in this publication was supported by the National Research Foundation (NRF) and Govan Mbeki Research and Development Centre (GMRDC), University of Fort Hare. The views and opinions expressed are not those of the NRF or GMRDC but of the author of the material published.

Conflicts of Interest: The author declares no conflict of interest.

\section{References}

1. Bosch, C.H. Bridelia micrantha (Hochst.) Baill. In Plant Resources of Tropical Africa 7(2). Timbers 2; Lemmens, R.H.M.J., Louppe, D., Oteng-Amoako, A.A., Eds.; PROTA Foundation: Wageningen, The Netherlands, 2012; pp. 169-171.

2. Schmidt, E.; Lotter, M.; McCleland, W. Trees and Shrubs of Mpumalanga and Kruger National Park; Jacana Publishers: Johannesburg, South Africa, 2002.

3. Radcliffe-Smith, A. Euphorbiaceae (Part 1). In Flora of Tropical East Africa; Polhill, P.M., Ed.; A.A Balkema: Rotterdam, The Netherlands, 1987; pp. 1-407.

4. Ngueyem, T.A.; Brusotti, G.; Caccialanza, G.; Finzi, P.V. The genus Bridelia: A phytochemical and ethnopharmacological review. J. Ethnopharmacol. 2009, 12, 339-349. [CrossRef] [PubMed]

5. Van Wyk, B.; Gericke, N. People's Plants: A Guide to Useful Plants of Southern Africa; Briza Publications: Pretoria, South Africa, 2000.

6. Walsh, M. The use of wild and cultivated plants as famine foods on Pemba Island, Zanzibar. Études Océan Indien 2012, 42-43, 217-241. Available online: http: / / oceanindien.revues.org/793 (accessed on 10 July 2017). [CrossRef]

7. Van Wyk, B.-E. The potential of South African plants in the development of new food and beverage products. S. Afr. J. Bot. 2011, 77, 857-868. [CrossRef]

8. Maghembe, J.A.; Prins, H. Performance of multipurpose trees for agroforestry two years after planting at Makoka, Malawi. For. Ecol. Manag. 1994, 64, 171-182. [CrossRef]

9. Kideghesho, J.R.; Msuya, T.S. Gender and socio-economic factors influencing domestication of indigenous medicinal plants in the West Usambara Mountains, northern Tanzania. Int. J. Biodivers. Sci. Ecosyst. Serv. Manag. 2010, 6, 3-12. [CrossRef]

10. Ingram, V.; Schure, J. Review of Non Timber Forest Products (NTFPs) in Central Africa: Cameroon; Center for International Forestry Research (CIFOR): Yaounde, Cameroon, 2010.

11. Meke, G.S.; Mumba, R.F.E.; Bwanali, R.J.; Williams, V.L. The trade and marketing of traditional medicines in southern and central Malawi. Int. J. Sustain. Dev. World Ecol. 2017, 24, 73-87. [CrossRef]

12. Oluwalana, E.O.A.; Adekunle, M.F.; Ayeni, A.A. Sales of medicinal forest tree barks in Abeokuta, Ogun State Nigeria. Afr. Res. Rev. 2007, 1, 57-64. [CrossRef]

13. Williams, V.L.; Balkwill, K.; Witkowski, E.T.F. A lexicon of plants traded in the Witwatersrand umuthi shops, South Africa. Bothalia 2001, 31, 71-98. [CrossRef]

14. Chekole, G.; Asfaw, Z.; Kelbessa, E. Ethnobotanical study of medicinal plants in the environs of Tara-gedam and Amba remnant forests of Libo Kemkem District, northwest Ethiopia. J. Ethnobiol. Ethnomed. 2015, 11, 4. [CrossRef] [PubMed]

15. Hamill, F.A.; Apio, S.; Mubiru, N.K.; Bukenya-Ziraba, R.; Mosango, M.; Maganyi, O.W.; Soejarto, D.D. Traditional herbal drugs of southern Uganda, II: Literature analysis and antimicrobial assays. J. Ethnopharmacol. 2003, 84, 57-78. [CrossRef]

16. Mbayo, K.M.; Kalonda, M.E.; Tshisand, T.P.; Kisimba, K.E.; Mulamba, M.; Richard, M.K.; Sangwa, K.G.; Mbayo, K.G.; Maseho, M.F.; Bakari, S.; et al. Contribution to ethnobotanical knowledge of some Euphorbiaceae used in traditional medicine in Lubumbashi and its surroundings (DRC). J. Adv. Bot. Zool. 2016, 4, 1-16.

17. Arnold, H.-J.; Gulumian, M. Pharmacopoeia of traditional medicine in Venda. J. Ethnopharmacol. 1984, 12, 35-74. [CrossRef]

18. Gelfand, M.; Mavi, S.; Drummond, R.B.; Ndemera, B. The Traditional Medical Practitioners in Zimbabwe: His Principles of Practice and Pharmacopoeia; Mambo Press: Gweru, Zimbabwe, 1985. 
19. Steenkamp, V.; Fernandes, A.C.; van Rensburg, C.E. Antibacterial activity of Venda medicinal plants. Fitoterapia 2007, 78, 561-564. [CrossRef] [PubMed]

20. Moshi, M.J.; Otieno, D.F.; Weisheit, A. Ethnomedicine of the Kagera region, north western Tanzania. Part 3: Plants used in traditional medicine in Kikuku village, Muleba district. J. Ethnobiol. Ethnomed. 2012, 8, 14. [CrossRef] [PubMed]

21. Betti, J.L. An ethnobotanical study of medicinal plants among the Baka pygmies in the Dja Biosphere reserve, Cameroon. Afr. Study Monogr. 2004, 25, 1-27.

22. Latham, P. Useful Plants of Bas-Congo Province, Democratic Republic of Congo; Department of International Development (DFID): London, UK, 2004.

23. Mabogo, E.E.N. The Ethnobotany of the Vhavenda; MSc dissertation, University of Pretoria: Pretoria, South Africa, 1990.

24. Venter, F.; Venter, J.-A. Making the Most of Indigenous Trees; Briza Publications: Pretoria, South Africa, 1996.

25. Lin, J.; Puckree, T.; Mvelase, T.P. Anti-diarrheal evaluation of some medicinal plants used by Zulu traditional healers. J. Ethnopharmacol. 2002, 79, 53-56. [CrossRef]

26. Munayi, R.R. Phytochemical Investigation of Bridelia micrantha and Tabernaemontana ventricosa for Cytotoxic Principles against Drug Sensitive Leukemia Cell Lines. Master's Thesis, University of Nairobi, Nairobi, Kenya, 2016.

27. Ochwang'I, D.O.; Kimwele, C.N.; Oduma, J.A.; Gathumbi, P.K.; Mbaria, J.M.; Kiama, S.G. Medicinal plants used in treatment and management of cancer in Kakamega County, Kenya. J. Ethnopharmacol. 2014, 151, 1040-1055. [CrossRef] [PubMed]

28. Focho, D.A.; Ndam, W.T.; Fonge, B.A. Medicinal plants of Aguambu-Bamumbu in the Lebialem highlands, southwest province of Cameroon. Afr. J. Pharm. Pharmacol. 2009, 3, 1-13.

29. Jiofack, T.; Fokunang, C.; Guedje, N.; Kemeuze, V.; Fongnzossie, E.; Nkongmeneck, B.A.; Mapongmetsem, P.M.; Tsabang, N. Ethnobotanical uses of medicinal plants of two ethnoecological regions of Cameroon. Int. J. Med. Med. Sci. 2010, 2, 60-79.

30. Madge, C. Therapeutic landscapes of the Jola, The Gambia, West Africa. Health Place 1998, 4, $293-311$. [CrossRef]

31. Koné, M.; Atindehou, K.K. Ethnobotanical inventory of medicinal plants used in traditional veterinary medicine in Northern Côte d'Ivoire (West Africa). S. Afr. J. Bot. 2008, 74, 76-84. [CrossRef]

32. Gangoué-Piéboji, J.; Eze, N.; Djintchui, A.N.; Ngameni, B.; Tsabang, N.; Pegnyemb, D.E.; Biyiti, L.; Ngassam, P.; Koulla-Shiro, S.; Galleni, M. The in vitro antimicrobial activity of some traditionally used medicinal plants against beta-lactam-resistant bacteria. J. Infect. Dev. Ctries. 2009, 3, 671-680. [CrossRef] [PubMed]

33. Idu, M.; Erhabor, J.O.; Ovuakporie-Uvo, O. Ethnomedicinal plants used by the Idoma people-Benue State, Nigeria. Am. J. Ethnomed. 2014, 1, 72-88.

34. Abo, K.A.; Fred-Jaiyesimi, A.A.; Jaiyesimi, A.E.A. Ethnobotanical studies of medicinal plants used in the management of diabetes mellitus in South Western Nigeria. J. Ethnopharmacol. 2008, 115, 67-71. [CrossRef] [PubMed]

35. Gbolade, A.A. Inventory of antidiabetic plants in selected districts of Lagos State, Nigeria. J. Ethnopharmacol. 2009, 121, 135-139. [CrossRef] [PubMed]

36. Mabeku, L.B.K.; Roger, K.J.; Louis, O.E.J. Screening of some plants used in the Cameroonian folk medicine for the treatment of infectious diseases. Int. J. Biol. 2011, 3, 13-21.

37. Diallo, A.; Traore, M.S.; Keita, S.M.; Balde, M.A.; Keita, A.; Camara, M.; van Miert, S.; Pieters, L.; Balde, A.M. Management of diabetes in Guinean traditional medicine: An ethnobotanical investigation in the coastal lowlands. J. Ethnopharmacol. 2012, 144, 353-361. [CrossRef] [PubMed]

38. Kokwaro, J.O. Medicinal Plants of East Africa; Kenya Literature Bureau: Nairobi, Kenya, 1993.

39. Bessong, P.O.; Obi, C.L.; Igumbor, E.; Andreola, M.-L.; Litvak, S. In vitro activity of three selected South African medicinal plants against human immunodeficiency virus type 1 reverse transcriptase. Afr. J. Biotechnol. 2004, 3, 555-559.

40. Bessong, P.O.; Rojas, L.B.; Obi, L.C.; Tshisikawe, P.M.I.; Eunice, O. Further screening of Venda medicinal plants for activity against HIV type 1 reverse transcriptase and Integrase. Afr. J. Biotechnol. 2006, 5, 526-528.

41. Ita, P.B.; Offiong, E.E. Medicinal plants used in traditional medicine by rural communities in Cross River State, Nigeria. J. Health Med. Nurs. 2013, 1, 23-29. 
42. Hallam, G.M. Medicinal Uses of Flowering Plants in the Gambia; Department of Forestry: Yundum, Gambia, 1979.

43. Nzigidahera, B. Assessment of Socio-Cultural, Economic Characteristics and Livelihood of Riparian Population of the Kibira National Park (Rukoma-Mutana Locality). 2006. Available online: https:/ /www.google.co.za/url $? \mathrm{sa}=\mathrm{t} \& \mathrm{rct}=\mathrm{j} \& \mathrm{q}=\& \mathrm{esrc}=\mathrm{s} \&$ source=web\&cd=1\&cad=rja\&uact=8\&ved=0ahUKEwjTsbeE9JHWAhWFKMAK HYmCApgQFgglMAA\&url=http \%3A\%2F\%2Fbi.chm-cbd.net\%2Frestored\%2Fbiodiversity \%2Fbiodiversite-d

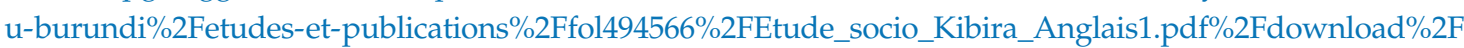
en\%2F1\%2FEtude_socio_Kibira_Anglais1.pdf\&usg=AFQjCNFdr0Q_BDN7ipaIsJG0SMCubGIpJg (accessed on 10 June 2017).

44. Hutchings, A.; Scott, A.H.; Lewis, G.; Cunningham, A. Zulu Medicinal Plants. An Inventory; University of Natal Press: Scottsville, South Africa, 1996.

45. Watt, J.M.; Breyer-Brandwijk, M.G. The Medicinal and Poisonous Plants of Southern and Eastern Africa; E. and S. Livingstone: London, UK, 1962.

46. Shelembe, B.G. Phytochemical and Elemental Studies of Two Indigenous Medicinal Plants of South Africa, Bridelia micrantha and Sideroxylon inerme. Master's Thesis, University of KwaZulu Natal, Durban, South Africa, 2014.

47. Catarino, L.; Havik, P.J.; Romeiras, M.M. Medicinal plants of Guinea-Bissau: Therapeutic applications, ethnic diversity and knowledge transfer. J. Ethnopharmacol. 2016, 183, 71-94. [CrossRef] [PubMed]

48. Frazão-Moreira, A. The symbolic efficacy of medicinal plants: Practices, knowledge, and religious beliefs amongst the Nalu healers of Guinea-Bissau. J. Ethnobiol. Ethnomed. 2016, 12, 24. [CrossRef] [PubMed]

49. Ariwaodo, J.O.; Chukwuma, E.C.; Adeniji, K.A. Some medicinal plant species of Asamagbe stream bank vegetation, Forestry Research Institute of Nigeria, Ibadan. Ethnobot. Res. Appl. 2012, 10, 541-549.

50. Chukwuma, E.C.; Soladoye, M.O.; Feyisola, R.T. Traditional medicine and the future of medicinal Plants in Nigeria. J. Med. Plants 2015, 3, 23-29.

51. Amri, E.; Kisangau, D.P. Ethnomedicinal study of plants used in villages around Kimboza forest reserve in Morogoro, Tanzania. J. Ethnobiol. Ethnomed. 2012, 8, 1. [CrossRef] [PubMed]

52. Njoroge, G.N.; Bussmann, R.W. Ethnotherapeutic management of sexually transmitted diseases (STDs) and reproductive health conditions in central province of Kenya. Indian J. Tradit. Knowl. 2009, 8, 255-261.

53. Verger, P.F. Ewe: The Use of Plants in Yoruba Society; Editoria Schwarcz: Sao Paulo, Brazil, 1995.

54. Palmer, E.; Pitman, P. Trees of Southern Africa Covering all Known Indigenous Species in the Republic of South Africa, South West Africa, Botswana, Lesotho and Swaziland; A.A. Balkema: Cape Town, South Africa, 1972.

55. Nole, T.; Lionel, T.D.W.; Cedrix, T.F.S.; Gabriel, A.A. Ethnomedical and ethnopharmacological study of plants used for potential treatments of diabetes and arterial hypertension by indigenous people in three phytogeographic regions of Cameroon. Diabetes Case Rep. 2016, 1, 110. [CrossRef]

56. Nguta, J.M.; Mbaria, J.M.; Gakuya, D.W.; Gathumbi, P.K.; Kiama, S.G. Traditional antimalarial phytotherapy remedies used by the South Coast community, Kenya. J. Ethnopharmacol. 2010, 131, 256-267. [CrossRef] [PubMed]

57. Traore, M.S.; Baldé, M.A.; Diallo, M.S.T.; Baldé, E.S.; Diané, S.; Camara, A.; Diallo, A.; Balde, A.; Keïta, A.; Keita, S.M.; et al. Ethnobotanical survey on medicinal plants used by Guinean traditional healers in the treatment of malaria. J. Ethnopharmacol. 2013, 150, 1145-1153. [CrossRef] [PubMed]

58. Malan, D.F.; Neuba, D.F.R.; Kouakou, K.L. Medicinal plants and traditional healing practices in ehotile people, around the aby lagoon (eastern littoral of Côte d'Ivoire). J. Ethnobiol. Ethnomed. 2015, 11, 21. [CrossRef] [PubMed]

59. Nondo, R.S.O.; Zofou, D.; Moshi, M.J.; Erasto, P.; Wanji, S.; Ngemenya, M.N.; Titanji, V.P.K.; Kidukuli, A.W.; Masimba, P.J. Ethnobotanical survey and in vitro antiplasmodial activity of medicinal plants used to treat malaria in Kagera and Lindi regions, Tanzania. J. Med. Plants Res. 2015, 9, 179-192.

60. Jeruto, P.; Mutai, C.; Ouma, G.; Lukhoba, C.; Nyamaka, R.L.; Manani, S.D. Ethnobotanical survey and propagation of some endangered medicinal plants from south Nandi district of Kenya. J. Anim. Plant Sci. 2010, 8, 1016-1043.

61. Ssegawa, P.; Kasenene, J.M. Medicinal plant diversity and uses in the Sango Bay area, southern Uganda. J. Ethnopharmacol. 2007, 113, 521-540. [CrossRef] [PubMed]

62. Okello, S.V.; Nyunja, R.O.; Netondo, G.W.; Onyango, J.C. Ethnobotanical study of medicinal plants used by Sabaots of Mt. Elgon Kenya. Afr. J. Tradit. Complement. Altern. Med. 2010, 7, 1-10. [CrossRef] 
63. Jeruto, P.; Too, E.; Mwamburi, L.A.; Amuka, O. An inventory of medicinal plants used to treat gynaecological obstetric-urino-genital disorders in South Nandi Sub County in Kenya. J. Nat. Sci. Res. 2015, 5, 136-152.

64. Zenebe, G.; Zerihun, M.; Solomon, Z. An ethnobotanical study of medicinal plants in Asgede Tsimbila district, northwestern Tigray, northern Ethiopia. Ethnobot. Res. Appl. 2012, 10, 305-320. [CrossRef]

65. Lebbie, A.R.; Guries, R.P. Ethnobotanical value and conservation of sacred groves of the Kpaa Mende in Sierra Leone. Econ. Bot. 1995, 49, 297-308. [CrossRef]

66. Chifundera, K. Livestock diseases and the traditional medicine in the Bushi area, Kivu province, Democratic Republic of Congo. Afr. Study Monogr. 1998, 19, 13-33.

67. Wasswa, P.; Olila, D. The in vitro ascaricidal activity of selected indigenous medicinal plants used in ethno veterinary practices in Uganda. Afr. J. Tradit. Complement. Altern. Med. 2006, 3, 94-103.

68. Kabore, A.; Traore, A.; Pare, S.; Sawadogo, B.C.; Kalkoumdo, G.; Tamboura, H.H.; Belem, A.M.G. Ethno-medicinal study of plants used in ectoparasites infections of ruminant livestock in Sahelian region of Burkina Faso, West Africa. J. Nat. Prod. Plant Resour. 2012, 2, 611-616.

69. Pegel, K.H.; Rogers, C.B. Constituents of Bridelia micrantha. Phytochemistry 1968, 7, 655-656. [CrossRef]

70. Okeleye, B.I.; Bessong, P.O.; Ndip, R.N. Preliminary phytochemical screening and in vitro anti-Helicobacter pylori activity of extracts of the stem bark of Bridelia micrantha (Hochst.) Baill. Euphorbiaceae). Molecules 2011, 16, 6193-6205. [CrossRef] [PubMed]

71. Waiganjo, N.; Ochanda, H.; Yole, D. Phytochemical analysis of the selected five plant extracts. Chem. Mater. Res. 2013, 3, 12-17.

72. Akinyeye, R.O.; Olatunya, A.M. Phytochemical screening and mineral composition of the bark of some medicinal trees in Ondo State, Nigeria. Med. Aromat. Plant Res. J. 2014, 2, 44-49.

73. Ejikeme, C.M.; Ezeonu, C.S.; Eboatu, A.N. Determination of physical and phytochemical constituents of some tropical timbers indigenous to Niger Delta area of Nigeria. Eur. Sci. J. 2014, 10, 247-270.

74. Douglas, K.; Gitonga, A. Antimicrobial activity of Bridelia micrantha and Grewia plagiophylla leaf extracts. Br. J. Pharm. Res. 2016, 12, 1-7. [CrossRef]

75. Mburu, C.; Kareru, P.G.; Kipyegon, C.; Madivoli, E.S.; Maina, E.G.; Kairigo, P.K.; Kimani, P.K.; Marikah, D.M. Phytochemical Screening of Crude Extracts of Bridelia micrantha. Eur. J. Med. Plants 2016, 16, 1-7. [CrossRef]

76. Ochwang'I, D.O.; Kimwele, C.N.; Oduma, J.A.; Gathumbi, P.K.; Kiama, S.G.; Efferth, T. Phytochemical screening of medicinal plants of the Kakamega county, Kenya commonly used against cancer. Med. Aromat. Plants 2016, 5, 277.

77. Shelembe, B.G.; Moodley, R.; Jonnalagadda, S.B. Secondary metabolites isolated from two medicinal plant species, Bridelia micrantha and Sideroxylon inerme and their antioxidant activities. Acta Pol. Pharm. Drug Res. 2016, 73, 1249-1257.

78. Green, E.; Obi, L.C.; Samie, A.; Bessong, P.O.; Ndip, R.N. Characterization of n-hexane subfraction of Bridelia micrantha (Berth) and its antimycobacterium activity. BMC Complement. Altern. Med. 2011, 11, 28. [CrossRef] [PubMed]

79. Waterman, C.; Smith, R.A.; Pontiggia, L.; DerMarderosian, A. Anthelmintic screening of sub-Saharan African plants used in traditional medicine. J. Ethnopharmacol. 2010, 127, 755-759. [CrossRef] [PubMed]

80. Samie, A.; Obi, C.L.; Bessong, P.O.; Namrita, L. Activity profiles of fourteen selected medicinal plants from rural Venda communities in South Africa against fifteen clinical bacterial species. Afr. J. Biotechnol. 2005, 4, 1443-1451.

81. Adefuye, A.O.; Samie, A.; Ndip, R.N. In Vitro evaluation of the antimicrobial activity of extracts of Bridelia micrantha on selected bacterial pathogens. J. Med. Plants Res. 2011, 5, 5116-5122.

82. Adefuye, A.; Ndip, R.N. Phytochemical analysis and antibacterial evaluation of the ethyl acetate extract of the stem bark of Bridelia micrantha. Pharmacogn. Mag. 2013, 9, 45-50. [PubMed]

83. Traoré, M.S.; Baldé, M.A.; Camara, A.; Baldé, E.S.; Diané, S.; Diallo, M.S.T.; Keita, A.; Cos, P.; Maes, L.; Pieters, L.; Baldé, A.M. The malaria co-infection challenge: An investigation into the antimicrobial activity of selected Guinean medicinal plants. J. Ethnopharmacol. 2015, 174, 576-581. [CrossRef] [PubMed]

84. Bum, E.N.; Ngah, E.; Mune, R.M.N.; Minkoulou, D.M.Z.; Talla, E.; Moto, F.C.O.; Ngoupaye, G.T.; Taiwe, G.S.; Rakotonirina, A.; Rakotonirina, S.V. Decoctions of Bridelia micrantha and Croton macrostachyus may have anticonvulsant and sedative effects. Epilepsy Behav. 2012, 24, 319-323. 
85. Adika, O.A.; Madubunyi, I.I.; Asuzu, I.U. Antidiabetic and antioxidant effects of the methanol extract of Bridelia micrantha (Hochst.) Baill. (Euphorbiaceae) leaves on alloxan-induced diabetic Albino mice. Comp. Clin. Pathol. 2012, 21, 945-951. [CrossRef]

86. Green, E.; Samie, A.; Obi, C.L.; Bessong, P.O.; Ndip, R.N. Inhibitory properties of selected South African medicinal plants against Mycobacterium tuberculosis. J. Ethnopharmacol. 2010, 130, 151-157. [CrossRef] [PubMed]

87. Onoja, S.; Ukwueze, C.; Ezeja, M.; Udeh, N. Antinociceptive and antioxidant effects of hydromethanolic extract of Bridelia micrantha stem bark. J. Exp. Integr. Med. 2014, 4, 273. [CrossRef]

88. Nwaehujor, C.O.; Udeh, N.E. Screening of ethyl acetate extract of Bridelia micrantha for hepatoprotective and antioxidant activities on Wistar rats. Asian Pac. J. Trop. Med. 2011, 4, 796-798. [CrossRef]

89. Nwaehujor, C.O.; Igile, G.O.; Akande, M.G. In vitro antioxidant potentials of some herbal plants from southern Nigeria. J. Med. Sci. 2013, 13, 56-61. [CrossRef]

90. Clarkson, C.; Maharaj, V.J.; Crouch, N.R.; Grace, O.M.; Pillay, P.; Matsabisa, M.G.; Bhagwandin, N.; Smith, P.J.; Folb, P.I. In vitro antiplasmodial activity of medicinal plants native to or naturalised in South Africa. J. Ethnopharmacol. 2004, 92, 177-191. [CrossRef] [PubMed]

91. Ajaiyeoba, E.; Ashidi, J.; Abiodun, O.; Okpako, L.; Ogbole, O.; Akinboye, D.; Falade, C.; Bolaji, O.; Gbotosho, G.; Falade, M.; et al. Antimalarial Ethnobotany: In vitro antiplasmodial activity of seven plants identified in the Nigerian Middle Belt. Pharm. Biol. 2005, 42, 588-591. [CrossRef]

92. Waiganjo, N.; Yole, D.; Ochanda, H. Anti-schistosomal activity of five plant extracts on Swiss white mice infected with Schistosoma mansoni. J. Pharm. Biol. Sci. 2014, 9, 49-53.

93. Adesina, J.M.; Ileke, K.D.; Yallappa, R.; Ofuya, T.I. Insecticidal evaluation of Bridelia micrantha and Dalbergia lactea aqueous extracts for the control of Podagrica uniforma (Jacoby) and Nisotra dilecta (Jacoby) (Coleoptera: Chysomelidae) infestation on okra. Agrivita J. Agric. Sci. 2016, 38, 269-274. [CrossRef]

94. Gangoué-Piéboji, J.; Baurin, S.; Frère, J.M.; Ngassam, P.; Ngameni, B.; Azebaze, A.; Pegnyemb, D.E.; Watchueng, J.; Goffin, C.; Galleni, M. Screening of some medicinal plants from Cameroon for B-Lactamase inhibitory activity. Phytother. Res. 2007, 21, 284-287. [CrossRef] [PubMed]

95. Ajaiyeoba, E.O.; Abiodun, O.; Falade, M.O.; Ogbole, N.O.; Ashidi, J.S.; Happi, C.T.; Akinboye, D.O. In vitro cytotoxicity studies of 20 plants used in Nigerian antimalarial ethnomedicine. Phytomedicine 2006, 13, 295-298. [CrossRef] [PubMed]

96. Steenkamp, V.; Mokoele, T.L.; van Rensburg, C.E.J. Toxicity testing of two medicinal plants, Bridelia micrantha and Antidesma venosum. Open Toxicol. J. 2009, 3, 35-38. [CrossRef]

97. Moshi, M.J.; Innocent, E.; Magadula, J.J.; Otieno, D.J.; Weisheit, A.; Mbabazi, P.K.; Nondo, R.S.O. Brine shrimp toxicity of some plants used as traditional medicines in Kagera Region, north western Tanzania. Tanzan. J. Health Res. 2010, 12, 63-70. [CrossRef] [PubMed]

98. Omosa, L.K.; Midiwo, J.O.; Masila, V.M.; Gisacho, B.M.; Munayi, R.; Francisca-Kamakama; Chemutai, K.P.; Elhaboob, G.; Saeed, M.E.M.; Hamdoun, S.; et al. Cytotoxicity of 91 Kenyan indigenous medicinal plants towards human CCRF-CEM leukemia cells. J. Ethnopharmacol. 2016, 179, 177-196. [CrossRef] [PubMed]

99. Osebe, T.; Mbaria, J.; Yole, D.; Odongo, D.; Nderitu, J.; Ochanda, H. Bioactivity and toxicity of Bridelia micrantha, Chenopodium ambrosoides and Ocimum americanum plant extracts. Int. J. Basic Clin. Pharmacol. 2017, 6, 5-11. [CrossRef]

100. Ndhlala, A.R.; Mupure, C.; Chitindingu, K.; Benhura, M.A.; Muchuweti, M. Antioxidant potentials and degrees of polymerization of six wild fruits. Sci. Res. Essay 2006, 1, 87-92.

101. Verdcourt, B.; Trump, E.C. Common Poisonous Plants of East Africa; Collins: London, UK, 1969.

(c) 2017 by the author. Licensee MDPI, Basel, Switzerland. This article is an open access article distributed under the terms and conditions of the Creative Commons Attribution (CC BY) license (http://creativecommons.org/licenses/by/4.0/). 